\title{
Evaluation of Antibiotic Alternatives Used in Orthopedic Departments of 2 Hospitals According to Rational Use of Antibiotics
}

\author{
Mehmet İşyar, ${ }^{1}$ Mustafa Doğan, ${ }^{2}$ Seyit Ali Gümüştaş, ${ }^{3}$ \\ İbrahim Yılmaz,, ${ }^{4}$ Bülent Bilir, ${ }^{5}$ Olcay Güler, \\ Gamze Varol Saraçoğlu, ${ }^{6}$ Mahir Mahiroğulları ${ }^{1}$
}

'Department of Orthopaedic and
Traumatology, İstanbul Medipol
Inniversity Facul, Turkey
Department of Infectious Diseases,
Namik Kemal University Faculty of
Medicine, Tekirdag, Turkey
${ }^{3}$ Republic of Turkey Ministry of
Health, General Secretariat of The
Public Hospitals Union,
Tekirdağ, Turkey
Health, State Hospital,
${ }^{4}$ Republic of Turkey Ministry of
Pharmacovigilance and Rational
Use Team, Tekirdağ, Turkey
Tepartment of Internal Medicine,
Namık Kemal University Faculty of
Medicine, Tekirdağ, Turkey
${ }^{6}$ Department of Public Health,
Namık Kemal University Faculty of
Medicine, Tekirdağ, Turkey

Submitted: 23.07 .2015 Accepted: 20.01.2016

Correspondence: Mehmet İşyar, İstanbul Medipol Üniv. Tıp Fak. Ortopedi ve Trav. Anabilim Dalı, 34214 Bağcılar, İstanbul, Turkey E-mail:misyar2003@yahoo.com

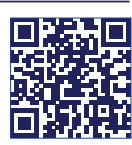

Keywords: Antibiotics surveillance; cost-effectiveness analyses; pharmacoeconomic model; rational antibiotic use.

\begin{abstract}
Objective: The present study is an analysis of appropriateness of antibiotics use for patients in whom infectious agent was detected. Data from patients in orthopedics and traumatology department of 2 hospitals in the same district were evaluated according to rational antibiotic drug use guidelines and culture antibiogram results.

Methods: Data of patients diagnosed with infection between January I, 2014 and December 3I, 2015 in orthopedics and traumatology department of 2 different hospitals were analyzed. Patients diagnosed with malignancy or who were discharged from other departments were excluded. A standard form was used to collect demographic data, culture antibiogram results, details of infectious agent, source of culture material, posology of antibiotic used, duration and appropriateness of use, and length of hospital stay. Costs were estimated based on number of units used and price per unit according to 2014 Ministry of Health price list. Mean price of antibiotics used per patient was calculated and descriptive analyses were also completed.
\end{abstract}

Results: It was determined that appropriate antibiotics for detected infectious agent were not always selected. Though there were effective, less expensive antibiotics that could have been used according to antibiogram results, more expensive antibiotics were often chosen, resulting in greater total cost.

Conclusion: Multidisciplinary approach in patient care and use of evidence-based guidelines should be increased. Teams should be formed and led by infectious disease and pharmacology specialists. New strategies should be developed immediately in health economics and new pharmacoeconomic models should be initiated in orthopedics and traumatology departments. 


\section{INTRODUCTION}

In recent years, it has been reported that orthopedic implants have been used more frequently in treatment of bone fractures and arthritis, and accordingly, a gradual increase in incidence of infection and antibiotic use has also been indicated. ${ }^{[1,2]}$

In parallel with the increase in antibiotic use, it has been acknowledged that other drugs and pharmacological products employed in treatment of infection incur excessive burden on total expenditures, social welfare institutions, and national economies. ${ }^{[3,4]}$ In addition, literature findings have demonstrated that appropriate treatment procedure for infectious diseases is important because of the serious threat to public health of antibacterial resistance, as well as its economic burden..$^{[5]}$

The fundamental target of healthcare providers, especially in treatment of infectious diseases, is to be able to administer proper, cost-effective, and individualized treatment within optimal time with minimal side effects. ${ }^{[6]}$ Therefore, rational drug use continues to be an important agenda item. Within this framework, international guidelines were prepared, and work groups and committees were established that are still actively performing their duties at local or national level. Many studies have confirmed widespread and irrational use of antibiotics. ${ }^{[7,8]}$

The present study is an analysis of antibiotic use and treatment costs for patients hospitalized and followed-up on for diagnosis of infection in the orthopedics and traumatology department of 2 different neighboring public hospitals using laboratory, clinical, and current guidelines. The secondary purpose of the study was to raise awareness about rational antibiotic use among orthopedic surgeons and other healthcare professionals.

\section{MATERIAL AND METHODS}

\section{Approval of ethics committee}

Approval of the ethics committee was obtained to conduct this multi-centered retrospective investigation.

\section{Selection of cases}

The study is an analysis of records from between January I, 2014 and December 3I, 2015 of the orthopedics and traumatology department of 2 neighboring secondary care public hospitals with approximately 400 beds each in Tekirdağ province. Hospital records regarding patient care and antibiotics used in 2812 cases treated in 30 beds in Hospital I (Group I) and 35 beds in Hospital 2 (Group 2), were examined.

Infectious agent detected in patients, length of hospital stay, antibiotics used, drug costs, and share of hospital budget were calculated and compared using electronic hospital information system and material sources management system.

Study population consisted of a total of 3068 patients (Hospital I: $n=1769$; Hospital 2: $n=1299$ ). Patients who were released on first day of hospitalization (Hospital I: $n=2$; Hospital 2: $n=6$ ), those with malignancy (Hospital I: $n=9$; Hospital 2: $n=17$ ), treatment refractory cases (Hospital I: $n=11$; Hospital 2: $n=9$ ), patients referred to another service (Hospital I: $n=43$; Hospital 2: $n=37$ ) or to another hospital (Hospital I: $n=61$; Hospital 2: $n=47$ ); patients who declined treatment (Hospital I: $n=9$; Hospital 2: $n=5$ ), and those who couldn't meet the study criteria (Hospital I: $n=135$; Hospital 2: $n=121$ ) were excluded. A total of 2812 patients were included in the study.

Demographic information, vital and laboratory findings (fever, white blood cell count [WBC], erythrocyte sedimentation rate [ESR], C-reactive protein [CRP], and if available, results of antibiotic susceptibility tests), data related to clinical diagnosis, antibiotic use (dose, duration, route of administration, information about prophylactic antibiotics), and approval of specialist in infectious diseases (according to guidelines of rational drug use and infection control committees) were recorded on pre-prepared standard information forms. In addition, conformity assessments were conducted after investigation of suitability of antibiotics used in light of drug usage information.

\section{Evaluation of costs}

Costs of drugs and pharmacological products were calculated by multiplying unit price by number of units used. Unit prices were determined based on price lists specified by Turkish Ministry of Finance and Turkish Ministry of Health Medicines and Medical Devices Agency. ${ }^{\left[{ }^{9]}\right.}$ Costs of nursing services and drug preparation costs were not taken into account.

Following calculation of direct cost of antibiotics, an additional pharmacoeconomic analysis was done based on selection of the least expensive antibiotic with equivalent benefit according to different methods of medical treatment and diagnosis. ${ }^{[10]}$ 


\section{Statistical analysis}

Data were calculated based on Turkish lira. Descriptive analyses were performed using Microsoft Office Excel program and presented as mean $\pm S D$ and percent change (frequency, percentage).

\section{RESULTS}

A total of 2812 cases were analyzed from Hospital I $(n=\mid 634,58.1 \%)$ and Hospital $2(n=\mid 178,41.9 \%)$. Hospital I cases consisted of 622 male (43.6\%) and 556 female patients with overall mean age of $52.97 \pm 20.47$ years. Mean age of patients in Hospital 2 was $49.03 \pm 20.12$ years; there were $(52.8 \%)$ male.

Mean hospital stay of inpatients in Hospital I was $5.7 I \pm 6.03$ days. Shortest hospital stay was I day, a patient with fractured distal end of tibia, and longest stay was IOI days, a patient with open wound on calf. In Hospital 2, mean hospital stay was $8.92 \pm 7.90$ days. The shortest stay was I day, also for patient with fractured distal end of tibia, while the longest hospital stay was 45 days, a patient who was diagnosed as osteomyelitis.

Antibiotic susceptibility tests were performed on patients in Hospital I who developed infection or who were hospitalized with diagnosis of infection based on culture antibiogram results of sputum $(n=1)$, urine $(n=10)$, and wound $(n=I 19)$ samples. Sputum cultures revealed growth of up- per respiratory tract flora. In urine cultures of 8 patients, no bacterial growth was detected, while in I patient, mixed bacterial growth was observed that was evaluated as contamination. No bacterial growth was detected in 77 wound site cultures, while 7 were evaluated as contamination with normal skin flora. In Hospital 2, significant bacterial growth was observed in 24 wound and 8 urine cultures (Table I).

Cost of drugs and pharmacological products and total hospital expenditures for department of orthopedics and traumatology were calculated for the year of the study (Table 2 ). Ratio of antibiotic drug costs to total cost of drugs and pharmacological products was estimated at $37.98 \%$ in Hospital I, and $33.43 \%$ in Hospital 2. Costs of antibiotics used in both hospitals are shown in Figure I.

In Hospitals I and 2, most frequently used drug was ceftriaxone (43405 vials, TL 432,747.86 and 39000 vials, TL $388,830.0$ I, respectively).

In the department of orthopedics and traumatology of Hospital I, cephazolin was most frequently used (10214 vials, TL 8,896.16), followed by imipenem (348 vials, TL 4,0I3). Hospital 2 department of orthopedics and traumatology also administered cephazolin most frequently (902I vials, TL 7,748.56), followed by ampicillin-sulbactam ( 2 I I 3 vials, TL 2,134.07).

In Hospitals I and 2, prophylactic cephazolin use for each patient was $6.25 \mathrm{~g}$ and $7.66 \mathrm{~g}$, respectively.

Table I. Frequently encountered infectious agents in patients hospitalized in the departments of orthopedics, and traumatology in two different hospitals

\begin{tabular}{lll}
\hline & Hospital I & Hospital II \\
\hline Urine sample & I & 0 \\
$\quad$ Candida spp. & 0 & 6 \\
Escherichia coli & & \\
Wound site material & 5 & 1 \\
Acinetobacter baumannii & 2 & 0 \\
Citrobacter braakii & 3 & 0 \\
Enterobacter cloacae & 0 & 2 \\
Enterococcus faecalis & 2 & 2 \\
Escherichia coli & 8 & 2 \\
ESBL (+) Escherichia coli & 1 & 2 \\
Methicillin-resistant Staphylococcus aureus & 0 & 3 \\
Staphylococcus haemoliyticus & 0 & 2 \\
Stenotrophomonas maltophilia & 1 & 2 \\
Proteus mirabilis & 3 & 2 \\
Pseudomonas aureginosa & &
\end{tabular}


Table 2. Comparison of hospital costs related to the consumption of DPH, and demographic characteristics

\begin{tabular}{lcc}
\hline & Hospital I (Piece/TL) & Hospital II (Piece/TL) \\
\hline Hospital cost related to DPH & $2.192 .155 / 3.952 .913 .13$ & $1.167 .169 / 1.986 .946 .16$ \\
Costs of DPH related to the Departments & $58881 / 86.405 .763$ & $53121 / 64.512 .37$ \\
of Orthopedics and Traumatology & & $13979 / 21.567 .39$ \\
Cost of only antibiotics & $13485 / 32.821 .47$ & \\
\hline DPH: Drugs, and pharmacological products. & &
\end{tabular}

Results of antibiotic susceptibility tests were analyzed, and instead of choosing a low-cost antibiotic sensitive to microorganism based on antimicrobial treatment guidelines, ${ }^{[1-13]}$ preference for expensive antibiotic group with broad spectrum was determined. For instance, in Hospital I, for 5 patients, instead of using lower cost antibiotics with higher sensitivity such as vancomycin, teicoplanin, erythromycin, or gentamycin, antibiotics with active ingredient of linezulid that have higher treatment cost were chosen without relevant justification $(n=5)$. In treatment of infections caused by microorganisms sensitive to piperacillin-tazobactam, cefepime, cefaperazone-sulbactam, gentamicin, and amikacin, meropenem group of antibiotics with higher treatment cost were chosen in 17 cases. In another 6 cases sensitive to less expensive ciprofloxacin, preference for levofloxacin was determined.

In Hospitals I and 2, inappropriate antibiotic was preferred instead of pharmaceutical alternative antibiotic with lower cost in $80 \%(n=28)$, and $71.88 \%(n=23)$ of cases, respectively.

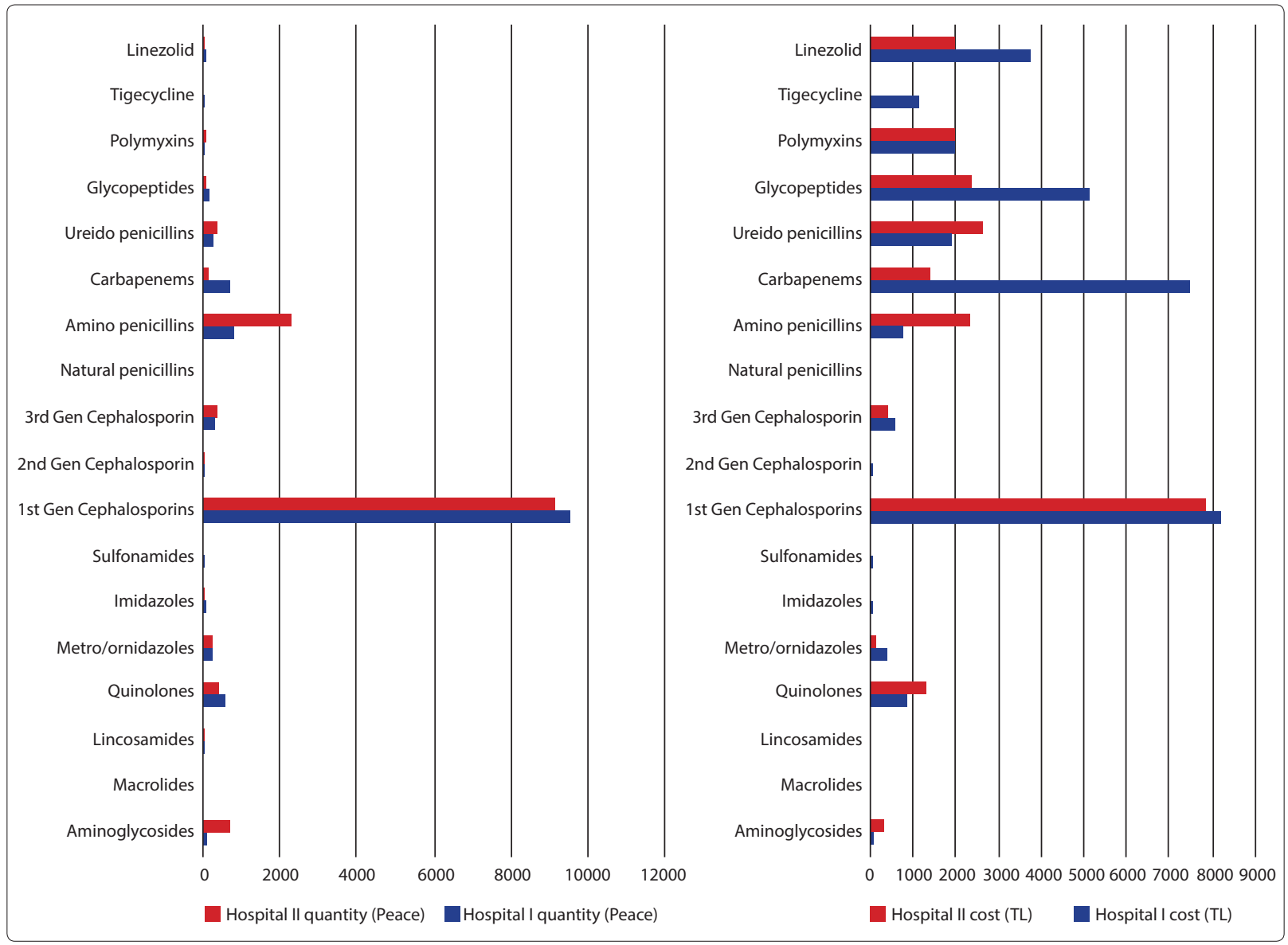

Figure 1. Comparisons of antibiotics used in patients hospitalized in two hospitals. 


\section{DISCUSSION}

Irrational antibiotic use directly affects public health due to development of resistant bacteria and increased morbidity and mortality rates, as well as indirectly by preventing allocation of necessary financial resources to health problems of top priority due to increase in health expenses. ${ }^{[14-16]}$

There have been reports from many European countries, including Turkey, of adverse outcomes concerning inappropriate antibiotic use and widespread antibiotic resistance. ${ }^{[17]}$

In a study where European countries were compared, it was emphasized that in France inappropriate use of antibiotics was a great public health problem, and antibiotics costs should be urgently reduced. ${ }^{[18-20]}$ In a study published by the World Health Organization (WHO) Regional Office for Europe, it was reported that in many countries, including Turkey, broad spectrum antibiotics were being used with increasing frequency, and that excessive use of thirdgeneration cephalosporins was indicated in Turkey. ${ }^{\left[{ }^{[1]}\right]}$

Preoperatively, for surgical prophylaxis, use of cephazolin at dose of I $\mathrm{g}$ has been recommended. ${ }^{[2]]}$

When patient data were evaluated, it was observed that active ingredient used for prophylaxis was the same employed in the literature. However, we detected extended period of prophylactic use of a certain dose of the active ingredient. In Hospitals I and 2, prophylactic cephazolin dose for each individual patient were $6.25 \mathrm{~g}$ and $7.66 \mathrm{~g}$, respectively.

Akgün et al. investigated risk factors related to development of surgical site infection in patients without systemic disease who had undergone elective orthopedic and neurosurgical surgeries. They reported that surgical site infection had developed in 13 patients, and that culture material obtained from 7 patients whose culture antibiogram tests revealed growth of Pseudomonas aeruginosa in $\mathrm{I}$, and Enterococcus faecalis in another patient. ${ }^{[22]}$

In the present study, culture medias of patients in Hospital I, growth of Acinetobacter baumanii $(n=3)$, Pseudomonas aeruginosa $(n=3)$, and extended spectrum pathogens grown in culture media were resistant to antibiotics.

In the same study, a survey was administered to II4 orthopedic surgeons who were members of the American Orthopedic Foot, and Ankle Society regarding use of prophylactic oral antibiotics. More than half $(63 \%)$ of the surgeons included in the study reported that they were using $500 \mathrm{mg}$ cephalexin at 6 hour-intervals for $5-7$ days for preoperative prophylaxis. They underlined the necessity of using a suitable cost-effective oral antibiotic that also overcomes resistance mechanism of pathogens. ${ }^{[23]}$

In the present study, it was observed that oral antibiotherapy was not preferred for pre- and postoperative periods in either hospital, which does not comply with literature data.

In an investigation by Karahocagil et al., authors indicated higher rates of antibiotic use with an incidence of $67.2 \%$ in departments of orthopedics and traumatology. ${ }^{[24]}$ Azap et al. reported that they didn't detect inappropriate use of antibiotherapy in patients in whom initiation of treatment was based on available microbiological data. ${ }^{[2]}$

Based on the results of the assessment of present study data, incidence rates of antibiotic use were $37.98 \%$ and $33.43 \%$, respectively, in Hospitals I and 2. In addition, inappropriate antibiotic use in terms of drug expenditure was observed in $80 \%(n=28)$ of patients in Hospital I, and $71.88 \%(n=23)$ of patients in Hospital 2.

Xu et al. reported that treatment plans for routine prophylactic antibiotic use in orthopedic surgery were not definitive, and indicated that as a result of extremely widespread and inappropriate antibiotic use, proliferation of antibiotic resistant pathogenic microorganisms resulting in increase in healthcare expenditures has been promoted. ${ }^{[26]}$ In another study, despite the limited amount of highquality evidence the authors presented, they indicated that adoption of clinical guidelines might improve clinical applications by decreasing variation and create conditions required for the multi-center studies necessary for systematic reviews. ${ }^{[2]]}$

Yüksek et al. conducted a study at a tertiary care research, and application hospital to research infectious agents isolated from inpatients and their antibiotic resistance patterns, and reported that infections are serious problems. They emphasized that knowledge about microorganisms grown in the culture media of the patients hospitalized in services would aid in the selection of appropriate empiric treatment and protection of the patients from contamination with resistant microorganisms. ${ }^{[28]}$

The current study investigated one of the important items related to drug expenditures, namely cost of antibiotics, and it is one of limited number of investigations that emphasize variations in antibiotic use and the related costs. Although the study has strong points, the fact that data 
were retrieved retrospectively from hospital archives is a limitation.

In this study it was indicated that antibiotics were most frequently used in Hospital I, ( 3485 pieces, total cost TL $32,821.47)$, and according to the results of antibiotic susceptibility tests, $80 \%$ of them incurred unnecessary financial burden. In Hospital 2, I 3979 pieces of antibiotics were used during the period studied at a cost of TL 2I,567.39; $71.88 \%$ of the antibiotics used were not appropriate based on antibiotic susceptibility test results.

According to the results found in this study, the participation of specialists in orthopedics and traumatology on the committees of infection control and rational drug use, as well as clinical pharmacologist and hospital pharmacist, is important in terms of raising awareness about rational antibiotic use and drug costs. Further studies should be conducted on this subject. Comprehensive scientific studies should be conducted in healthcare institutions, including departments of orthopedics and traumatology of tertiary care hospitals, and data obtained should be shared.

\section{REFERENCES}

1. Ambrose CG, Clyburn TA, Mika J, Gogola GR, Kaplan HB, Wanger A, et al. Evaluation of antibiotic-impregnated microspheres for the prevention of implant-associated orthopaedic infections. J Bone Joint Surg Am 2014;96:128-34.

2. Macias J, Grajek A, Bogut A, Białecki J, Marczyński W, Rak S, et al. The effects of cooperation between orthopaedic surgeons and microbiologists on the effectiveness of diagnosis and treatment of septic hip joint loosening. Pol Orthop Traumatol 2013;78:219-22.

3. Hoogendoorn M, Feenstra TL, Asukai Y, Borg S, Hansen RN, Jansson SA, et al. Cost-effectiveness models for chronic obstructive pulmonary disease: cross-model comparison of hypothetical treatment scenarios. Value Health 2014;17:525-36.

4. Lenferink A, Frith P, van der Valk P, Buckman J, Sladek R, Cafarella $\mathrm{P}$, et al. A self-management approach using self-initiated action plans for symptoms with ongoing nurse support in patients with Chronic Obstructive Pulmonary Disease (COPD) and comorbidities: the COPE-III study protocol. Contemp Clin Trials 2013;36:81-9.

5. Nolte E, Mckee M. Caring for people with chronic conditions. Berkshire, England: Open University Press; 2008. p. 141-9.

6. Wettengel R. Longterm treatment of COPD with theophylline-still a valuable option? Pneumologie 2003;57:598-605.

7. Malo S, Bjerrum L, Feja C, Lallana MJ, Poncel A, Rabanaque MJ. Antibiotic prescribing in acute respiratory tract infections in general practice. An Pediatr (Barc) 2015;82:412-6.

8. Joergensen JS, Kjær Weile LK, Lamont RF. The early use of appropriate prophylactic antibiotics in susceptible women for the prevention of preterm birth of infectious etiology. Expert Opin Pharmacother 2014;15:2173-91.

9. Ministriy of Health. Price list for drugs, 2014, (http://www.iegm.gov. tr. Available at 09.03.2015.
10. Smith MC, Wertheimer AI. Predicting and detecting non compliance. Social and behavioral aspects of pharmaceutical care. New York: Pharmaceutical Products Press; 1996. p. 165-9.

11. Sanford Guide to Anitmicrobial Therapy. (http:/www.sanfordguide. com. Available at 22.05.2015.

12. Kalafat H. Hastane enfeksiyonları: korunma ve kontrol sempozyumu dizisi. İçinde: Perioperatif Antibiyotik Profilaksisi. (http://www.ctf. edu.tr/stek/pdfs/60/6018.pdf Available at 25.12.2015).

13. Young B, Ng TM, Teng C, Ang B, Tai HY, Lye DC. Nonconcordance with surgical site infection prevention guidelines and rates of surgical site infections for general surgical, neurological, and orthopedic procedures. Antimicrob Agents Chemother 2011;55:4659-63.

14. Remesh A, Gayathri AM, Singh R, Retnavally KG. The knowledge, attitude and the perception of prescribers on the rational use of antibiotics and the need for an antibiotic policy-a cross sectional survey in a tertiary care hospital. J Clin Diagn Res 2013;7:675-9.

15. le Grand A, Hogerzeil HV, Haaijer-Ruskamp FM. Intervention research in rational use of drugs: a review. Health Policy Plan 1999;14:89-102.

16. Olukman O, Atlıhan F, Gülfidan G, Öztürk IC. Nosocomial infection agents and antibiotic resistance profiles in neonatal intensive care unit: an experience of one year. J Exp Clin Med 2009;26:72-6.

17. Dogan M, Mutlu LC, Yilmaz İ, Bilir B, Varol Saracoglu G, Yildirim Guzelant A. Are treatment guides and rational drug use policies adequately exploited in combating respiratory system diseases? J Infect Public Health 2016;9:42-51.

18. Versporten A, Bolokhovets G, Ghazaryan L, Abilova V, Pyshnik G, Spasojevic T, et al. Antibiotic use in eastern Europe: a cross-national database study in coordination with the WHO Regional Office for Europe. Lancet Infect Dis 2014;14:381-7.

19. Saraçoğlu GV, Göçmez S, Özkal C, Ekmekyapar F, Meriç S. Occurence of antibiotics in urban wastewater: A risk assessment study in Tekirdağ city related to antibiotic resistant bacteria and infection disease control, Global Journal on Advances in Pure \& Applied Sciences 2014. p. 235-44. Available from: http://www.world-education-center.org/index.php/paas (Selected Paper of 1st World Conference on Health Sciences (H-SCI 2014).

20. Geissler A, Gerbeaux P, Granier I, Blanc P, Facon K, Durand-Gasselin J. Rational use of antibiotics in the intensive care unit: impact on microbial resistance and costs. Intensive Care Med 2003;29:49-54.

21. Öncü S. Antibiotic prophylaxis in surgery. Turkish Journal of Surgery 2011;27:176-81.

22. Meftun Akgün. The risk factors effecting the development of surgical site infection in orthopedic and neuro surgery patients without systemic disease. MÜSBED 2012;2:181-9.

23. Ruta DJ, Kadakia AR, Irwin TA. What are the patterns of prophylactic postoperative oral antibiotic use after foot and ankle surgery? Clin Orthop Relat Res 2014;472:3204-13.

24. Karahocagil MK. Er A, Kırıkçı AD, Sünnetçioğlu M, Yapıcı K, Bilici A, et al. Evaluation Of Antibiotic Use In Patients Hospitalized In Yüzüncü Yil University Medical Faculty Research Hospital. Van Tip Dergisi 2007;14:46-51.

25. Azap A, Memikoğlu KO, Çokça F, Tekeli E, et al. The Antibiotic Usage Before and After a Nationwide Antibiotic Restriction Policy at a University Hospital. Flora 2004;9:252-7.

26. Xu SG, Mao ZG, Liu BS, Zhu HH, Pan HL. Evaluating the use of antibiotic prophylaxis during open reduction and internal fixa- 
tion surgery in patients at low risk of surgical site infection. Injury 2015;46:184-8.

27. Minassian AM, Osmon DR, Berendt AR. Clinical guidelines in the management of prosthetic joint infection. J Antimicrob Chemother
2014;69:29-35.

28. Yüksek A. The causative agents of infections in intensive care unit and their antibiotic resistance patterns. Int J Basic Clin Med 2013;1:1-6.

\section{İki Farklı Hastanenin Ortopedi Kliniklerinde z Antibiyotik Seçeneklerinin Akılcı Antibiyotik Kullanımı Açısından Değerlendirilmesi}

Amaç: Birbirine yakın ve aynı bölgede yer alan iki farklı hastanenin ortopedi ve travmatoloji servislerinde yatan hastalarda, etkeni saptanan enfeksiyon olgularında antibiyotik kullanımının, akılcı ilaç tedavi rehberleri ve kültür antibiyogram sonuçlarına göre uygunluğunun araştırılması amaçlandı.

Gereç ve Yöntem: Bu araştırma projesi T.C. Sağlık Bakanlığı Genel Sekreterlik İzni doğrultusunda 0I Ocak 20 I4 ile 3 I Aralık 20 I4 tarihleri arasında, iki hastanenin ortopedi ve travmatoloji servislerinde enfeksiyon tanısına sahip olguların verileri üzerinden gerçekleştirildi. Malignitesi olan veya başka bir servise taburcu edilen olgular çalışmadan dışlandı. Standart bir form oluşturuldu. Bu form içerisine, olguların demografik verilerine ek olarak, kültür antibiyogram sonuçları, enfeksiyon patojen etkeni, kültür materyalinin nereden alındığı, kullanılan antibiyotiklerin pozolojisi, süresi ve uygunluğu ile olguların yatış süreleri raporlandı. Maliyetlerin hesaplanmasında, Sağlık Bakanlığı ve Maliye Bakanlığı 20 ।4 yılı fiyat listeleri temel alındı. Birim fiyat üzerinden hasta başına kullanılan antibiyotik maliyetleri hesaplandı.

Bulgular: Saptanan enfeksiyon etkeni için her zaman uygun antibiyotiğin seçilmediği belirlendi. Antibiyogram sonuçlarına göre etkili, daha düşük maliyetli antibiyotikler kullanılabilinmesine rağmen sıklıkla daha pahalı ve toplam maliyeti yükselten antibiyotikler seçilmiştir.

Sonuç: Kanıta dayalı tıp ve akılcı antibiyotik kullanımı kapsamında enfeksiyon tedavisinde kültür antibiyogram sonuçlarına göre uygun antibiyotik seçilmesi gerekliliği tartışılmaz bir bilimsel gerçektir. Ortopedi ve travmatoloji servislerinde enfeksiyon tedavisinde enfeksiyon hastalıkları ve farmakoloji uzmanlarını da sürece katarak multi-disipliner yaklaşılarak kanıta dayalı rehberlerin kullanımının artışı sağlanmalıdır.

Anahtar Sözcükler: Akılcı antibiyotik kullanımı; antibiyotik surveyansı; farmakoekonomi; maliyet-etkililik analizi. 